\title{
A small amount of inhaled nitric oxide does not increase lung diffusing capacity
}

\author{
G.S. Zavorsky and J.M. Murias
}

ABSTRACT: The aim of the present study was to determine: 1) whether 40-50 ppm nitric oxide (NO) increases diffusing capacity of the lung for NO (DL,NO) and carbon monoxide ( $D L, C O)$, membrane diffusing capacity for $C O(D m, C O)$ and pulmonary capillary blood volume $\left.\left(V_{c}\right) ; 2\right)$ the actual number of tests required to provide a reasonable estimate of $D L, N O, D L, C O, D m, C O$ and $V_{c}$; and 3) repeatability of these parameters using the single-breath DL,NO-DL,CO method.

In total, 31 subjects performed five single-breath hold manoeuvres at rest, inhaling $43 \pm 3$ ppm NO together with a standard diffusion mixture.

$D L, N O(D m, C O)$ remained unchanged from the first to fifth trial. However, compared with the first trial, DL,Co and $V_{c}$ had decreased by the fourth $(-4 \pm 5 \%$; $95 \%$ confidence interval $(\mathrm{Cl})=-5--2 \%)$ and third trial $(-5 \pm 7 \% ; 95 \% \mathrm{Cl}=-7--2 \%)$, respectively. Repeatability over five trials was 17,3 and $7 \mathrm{~mL} \cdot \mathrm{min}^{-1} \cdot \mathrm{mmHg}^{-1}$ for $D \mathrm{~L}, \mathrm{NO}, D \mathrm{~L}, \mathrm{CO}$ and $D \mathrm{~m}, \mathrm{CO}$, respectively, and $13 \mathrm{~mL}$ for $V_{c}$ when $D \mathrm{~m}, \mathrm{CO}=\mathrm{DL}, \mathrm{NO} / 2.42$.

In conclusion, nitric oxide inhaled during sequential single-breath manoeuvres has no effect on diffusing capacity of the lung for nitric oxide and, thus, membrane diffusing capacity for carbon monoxide. Since more than two and three trials will lower pulmonary capillary blood volume and diffusing capacity of the lung for carbon monoxide, respectively, the average value of only two properly performed trials is suggested.

KEYWORDS: Diffusing capacity, nitric oxide, repeatability

$\mathbf{T}$

he equation of the diffusing capacity of the lung for carbon monoxide $(D \mathrm{~L}, \mathrm{CO})$ has been classically described as:

$$
1 / D_{\mathrm{L}, \mathrm{CO}}=\left(1 / D_{\mathrm{m}, \mathrm{CO}}\right)+\left(1 / \Theta \mathrm{CO} \cdot V_{\mathrm{c}}\right)
$$

where $D \mathrm{~m}, \mathrm{CO}$ represents pulmonary membrane diffusing capacity for carbon monoxide (CO) and $\Theta C O$ is the specific blood transfer conductance for $\mathrm{CO} . V_{\mathrm{c}}$ represents pulmonary capillary blood volume [1]. Membrane resistance $(1 / D \mathrm{~m}, \mathrm{CO})$ and red cell resistance $\left(1 / \Theta C O \cdot V_{c}\right)$ usually contribute equally to the overall diffusive resistance across the lung [2], although this has been debated [3]. To obtain $D \mathrm{~m}, \mathrm{CO}$ and $V_{\mathrm{c}}, D \mathrm{~L}, \mathrm{CO}$ has been traditionally measured at two different levels of alveolar oxygen tension $\left(P \mathrm{~A}, \mathrm{O}_{2}\right), \sim 13.3-16.0 \mathrm{kPa}$ $(\sim 100-120 \mathrm{mmHg})$ and $\sim 79.8 \mathrm{kPa}(\sim 600 \mathrm{mmHg})$. For each level of $P \mathrm{~A}_{1} \mathrm{O}_{2}, 1 / D \mathrm{~L}, \mathrm{CO}$ is then plotted on the $y$-axis and $1 / \Theta C O$ is plotted on the $x$-axis. A line is then drawn through two points and the $x-$ intercept $(1 / D \mathrm{~m}, \mathrm{CO})$ and slope $\left(1 / V_{\mathrm{c}}\right)$ can be solved. This two-step method can be time consuming and uncomfortable to perform, especially during exercise.

However, over the past 15 yrs, the measurement of diffusing capacity of the lung using the transfer gases nitric oxide (NO) and $\mathrm{CO}$ together permits one to obtain $D \mathrm{~m}, \mathrm{CO}$ and $V_{\mathrm{c}}$ in a singlebreath manoeuvre, thus allowing a similar distribution of the two gases and reducing the number of measurements and testing time by half $[4,5]$. The velocity constant of the combination of NO with haemoglobin is about 280 times faster than that of $\mathrm{CO}[6]$, and thus the specific blood transfer conductance for $\mathrm{NO}(\Theta \mathrm{NO})$ is so large that the red cell resistance to NO $(1 / \Theta N O)$ approaches zero [7]. Therefore, diffusing capacity of the lung for nitric oxide $(D \mathrm{~L}, \mathrm{NO})$ equals the membrane diffusing capacity for $\mathrm{NO}(D \mathrm{~m}, \mathrm{NO})$, and is independent of $V_{\mathrm{c}}$ and haemoglobin concentration [8]. Others have made the same assumption that $(1 / \Theta N O)$ is negligible [9-14], and it was recently determined that a nonzero 1/ @NO would not be able to explain their experimental data [12]. Therefore, these data suggest that $D \mathrm{~L}, \mathrm{NO}$ is a good measure of $D \mathrm{~m}, \mathrm{NO}$. Given that the molecular weight of $\mathrm{CO}$ and $\mathrm{NO}$ are 28 and $30 \mathrm{~g} \cdot \mathrm{M}^{-1}$, respectively, and solubilities (Bunsen coefficients) of $\mathrm{CO}$ and $\mathrm{NO}$ in plasma at $37^{\circ} \mathrm{C}$ are 0.0215 and 0.0439 [15], respectively, the diffusivity of NO, which is the solubility of $\mathrm{NO}$ divided by the square root of the molecular weight (MW) of NO $(\sqrt{\mathrm{MWNO}})$, is $\sim 1.97$ times
AFFILIATIONS

Dept of Anesthesia, McGill University Health Center, Montreal, Canada.

CORRESPONDENCE

G.S. Zavorsky

Dept of Anesthesia

McGill University Health Center

Montreal General Hospital

1650 Cedar Avenue

Room D10-144

Montreal

Quebec H3G 1A4

Canada

Fax: 15149348249

E-mail: gerald.zavorsky@mcgill.ca

Received:

December 122005

Accepted after revision:

February 242006 
greater than that of $\mathrm{CO}$ and, thus, the theoretical factor between membrane diffusing capacities for $\mathrm{NO}$ and $\mathrm{CO}$ is:

$(\mathrm{NO}$ solubility $/ \sqrt{\mathrm{MWNO}}) /(\mathrm{CO}$ solubility $/ \sqrt{\mathrm{MWCO}})=1.97$

Indeed, the solubility of either gas will depend upon the composition of the fluid that the gas has to diffuse through. If the fluid changes composition, the relative solubilities may well be different pre- and post-exercise. Nevertheless, data obtained from sick and healthy patients performing rebreathing manoeuvres suggest that the actual ratio of $D$ L,NO to $D$ m, CO is $\sim 2.42[11,12]$. The larger ratio may be due to a higher than assumed NO solubility in plasma as well as NO facilitated diffusion [12].

Several researchers have previously obtained $D \mathrm{~L}, \mathrm{NO}$ from single-breath $[4,5,9,10,13,14,16-19]$ or rebreathing manoeuvres [11, 12], along with the simultaneous measurement of $D \mathrm{~L}, \mathrm{CO}$ to obtain $D \mathrm{~m}, \mathrm{CO}$ and $V_{\mathrm{c}}$. Since brief exposure to NO does not interfere with physiological function [11, 12, 20, 21], it seems pertinent to use NO as a test gas to assess lung diffusion capacity. However, there is still debate as to whether inhalations of high NO concentrations ( $40-50 \mathrm{ppm})$ during sequential single-breath manoeuvres can affect the pulmonary microcirculation. At those $\mathrm{NO}$ concentrations, pulmonary vasodilation may occur, increasing $D \mathrm{~L}, \mathrm{CO}, V_{\mathrm{c}}$ and perhaps $D \mathrm{~L}, \mathrm{NO}(D \mathrm{~m}, \mathrm{CO})[22]$. Therefore, the first objective of the present study was to determine whether five sequential single breathhold manoeuvres inhaling $\sim 40 \mathrm{ppm}$ of $\mathrm{NO}$ increase $D \mathrm{~L}, \mathrm{CO}$, $D$ L,NO (and thus $D \mathrm{~m}, \mathrm{CO}$ ) and $V_{\mathrm{c}}$. The current hypothesis was that five repeated inhalations of 40-50 ppm of NO would not increase $D \mathrm{~L}, \mathrm{CO}, D \mathrm{~L}, \mathrm{NO}(D \mathrm{~m}, \mathrm{CO})$ or $V_{\mathrm{c}}$.

Furthermore, the recent 2005 American Thoracic Society (ATS)/European Respiratory Society (ERS) task force guidelines of standardisation of the single-breath determination of $\mathrm{CO}$ uptake in the lung [23] mentioned that more research is needed to determine the actual number of tests required to provide a reasonable estimate of the average $D \mathrm{~L}, \mathrm{CO}$. Therefore, the second objective of the current study was to determine the actual number of tests required to provide a reasonable estimate of not only $D \mathrm{~L}, \mathrm{CO}$, but $D \mathrm{~L}, \mathrm{NO}(D \mathrm{~m}, \mathrm{CO})$ and $V_{\mathrm{c}}$ for a given person. The present authors' hypothesis was that an average of three measurements would be needed to obtain a reasonable estimate of all those parameters.

The third objective was to determine the repeatability of lung diffusing capacity and its components over five trials in a given patient using the newer single-breath method of $\mathrm{CO}$ and NO. This would help to decide whether a change in an observation of $D \mathrm{~L}, \mathrm{NO}, D \mathrm{~L}, \mathrm{CO}, D \mathrm{~m}, \mathrm{CO}$ and $V_{\mathrm{c}}$ represents a real clinical change in the pulmonary system or just measurement error. The current authors' hypothesis was that the repeatability for $D \mathrm{~L}, \mathrm{NO}, \mathrm{DL}, \mathrm{CO}$ and $D \mathrm{~m}, \mathrm{CO}$ would be 10,2 and $6 \mathrm{~mL} \cdot \mathrm{min}^{-1} \cdot \mathrm{mmHg}^{-1}$, respectively, and $10 \mathrm{~mL}$ for $V_{\mathrm{c}}$.

\section{METHODS}

\section{Subjects}

In total, 31 healthy subjects were recruited (15 females, 16 males) and all completed the study (aged $33 \pm 9$ yrs; weight $68.6 \pm 12.5 \mathrm{~kg}$; height $169.9 \pm 9 \mathrm{~cm}$ ). All subjects were nonsmokers. These subjects had normal resting spirometry function (forced expiratory volume in one second (FEV1) $>80 \%$ predicted, and FEV1/forced vital capacity (FVC)
$>0.70$ ) and no history of cardiopulmonary disease. Each subject was required to come into the laboratory on one occasion only.

\section{Single-breath apparatus and technique}

Volume and gas calibration of the Ergocard and the Hyp'Air lung diffusion system (Medisoft, Dinant, Belgium) were performed prior to each testing session. The subjects breathed through a three-way pneumatic valve developed by Medisoft. A dead space washout volume of $900 \mathrm{~mL}$ was allowed, and an expired sample volume of $900 \mathrm{~mL}$ was collected. The instrument dead space was measured at $140 \mathrm{~mL}$ (including the mouthpiece, valve and filter dead spaces). Anatomical dead space $(\mathrm{mL})$ was estimated as bodyweight in $\mathrm{kg} \times 2.2$ [23]. The concentrations of inspiratory gases were $0.295 \% \mathrm{CO}, 9.96 \% \mathrm{He}$, $20.98 \% \mathrm{O}_{2}$ and balance $\mathrm{N}_{2}$ for gas mixture one, and 1,000 ppm $\mathrm{NO}$ and balance $\mathrm{N}_{2}$ for gas mixture two. A third mixture of 77 ppm $\mathrm{NO}$ and balance $\mathrm{N}_{2}$ was used for calibration purposes only. For the single-breath manoeuvre, an inspiratory bag was filled with 5-8 L depending on the subject's FVC using the first two gas mixtures. Once the mixtures were injected into the inspiratory bag, the concentration of $\mathrm{CO}, \mathrm{He}, \mathrm{NO}$, and $\mathrm{O}_{2}$ were analysed simultaneously over $30 \mathrm{~s}$ by gas analysers. The injection of the various gas mixtures into the inspiratory bag resulted in approximate inspired concentrations of $\mathrm{CO}, \mathrm{He}$, $\mathrm{NO}$ and $\mathrm{O}_{2}$ at $0.30 \%, 9 \%, 40 \mathrm{ppm}$ and $20 \%$, respectively. The types of gas analysers used for measuring inspired and expired gas mixtures have been reported elsewhere [13]. Inspired volume was measured, corrected for instrument and anatomical dead space, and converted to standard temperature, pressure and dry conditions. Breath-holding time was calculated using the method of JONES and MEADE [24].

\section{Calculation of diffusion capacities, $\mathrm{Dm}$ and $\mathbf{V}_{\mathbf{c}}$}

Diffusion capacities for NO and CO were calculated simultaneously from the exponential disappearance rate of each gas with respect to He using the method by JONES and MEADE [24]. The formulae for calculating DL,CO can be found in the 2005 ATS/ERS guidelines [23]. All results were standardised to a haemoglobin $(\mathrm{Hb})$ concentration of $14.6 \mathrm{~g} \cdot \mathrm{dL}^{-1}$ for males and $12.0 \mathrm{~g} \cdot \mathrm{dL}^{-1}$ for females, and a $P \mathrm{~A}_{,} \mathrm{O}_{2}$ of $13.3 \mathrm{kPa}(100 \mathrm{mmHg})$ by inserting these values into the following formula by ROUGHTON and FORSTER [1]:

$$
(1 / \Theta C O)=\left(0.73+0.0058 \times P_{\mathrm{O}_{2}}\right) \times(14.6 /[\mathrm{Hb}])
$$

where $1 / \Theta C O$ was 1.426 and $\Theta C O$ was $0.701 \mathrm{~mL} \cdot \mathrm{min}^{-1}$. $\mathrm{mmHg}^{-1}$ for males, $1 / \Theta C O$ was 1.594 and $\Theta C O$ was $0.627 \mathrm{~mL}$. $\mathrm{min}^{-1} \cdot \mathrm{mmHg}^{-1}$ for females and $\mathrm{PO}_{2}$ was partial pressure of oxygen. A DL,NO to $D \mathrm{~m}, \mathrm{CO}$ ratio of $2.42[11,12,14]$ and 1.97 [5, $9,10,13,19]$ was used as the theoretical ratio of $D$ L,NO to $\mathrm{Dm}, \mathrm{CO}$ during single-breath manoeuvres since those ratios have both been used in the past. The ratio of 2.42 has been determined recently during rebreathing manoeuvres at rest and during exercise $[11,12]$, which can result in $D \mathrm{~m}, \mathrm{CO}$ values that are more in line with the current normative values [25]. Therefore, due to the two different $D \mathrm{~L}, \mathrm{NO}$ to $\mathrm{Dm}, \mathrm{CO}$ ratios reported in the literature, the current authors reported two different $D$ m,CO values and two different $V_{\mathrm{c}}$ values.

A breath-holding time of 4-5 s was chosen because it has been shown that $D L, C O$ values were not different with a 3- or 5-s 
breath hold compared with a 7- and 10-s breath hold [26] and a breath-holding time of $\sim 9 \mathrm{~s}$ would result in a less than detectable amount of expired NO [4]. The present authors did not account for $\mathrm{NO}$ back pressure in the calculations since exhaled NO concentrations at rest are negligible, ranging 11$66 \mathrm{ppb}(0.011-0.066 \mathrm{ppm})$ [27], which tend to decrease during exercise [28]. The amount of NO back pressure then would minimally affect $D \mathrm{~L}, \mathrm{NO}$ calculations as the measurements were carried out in the ppm range, which is $\sim 75-500$ times larger than the exhaled NO concentration at rest or during exercise after a single-breath inspiration of 40-60 ppm NO. Accounting for $\mathrm{CO}$ back pressure is also negligible as it has been shown that 2 min between tests virtually eliminates all the $\mathrm{CO}$ gas from the lungs in healthy subjects [29]. As the recent ATS/ERS guidelines recommend a minimum of $4 \mathrm{~min}$ between $D \mathrm{~L}, \mathrm{CO}$ measurements [23], subjects performed the single-breath manoeuvre with a minimum of 4.5 min between tests. Five sequential diffusion capacity tests were performed.

\section{Statistical analyses}

A one-way repeated measures ANOVA was used to determine if there were significant differences in $D \mathrm{~L}, \mathrm{CO}, D \mathrm{~L}, \mathrm{NO}, D \mathrm{~m}, \mathrm{CO}$ and $V_{\mathrm{c}}$ between the five trials. A Tukeys/Kramer post hoc comparison test was used to see where the differences in the five trials occurred. In addition, the variables height, age and weight were examined by forward stepwise multiple regression to determine which and what combination most predicted $D \mathrm{~L}, \mathrm{NO}$ values at rest. The measurement error for $D \mathrm{~L}, \mathrm{NO}, D \mathrm{~m}, \mathrm{CO}$, $D \mathrm{~L}, \mathrm{CO}$ and $V_{\mathrm{c}}$ was calculated as the square root of the residual mean square error (which is also called the within-subject standard deviation) obtained from the one-way repeated measures ANOVA [30]. The repeatability of each variable was then obtained multiplying the within-subject standard deviation by 2.77 [30]. A p-value of $<0.05$ was considered statistically significant.

\section{RESULTS}

Of the 31 subjects, 29 had normal spirometry function (table 1) based on the fact that FEV1 was $>80 \%$ pred for all subjects, and the FEV1/FVC was $>0.7$ for all but two subjects (FEV1/FVC 0.67 and 0.68 , respectively). The single breath-hold manoeuvres, on the whole, were performed adequately (table 2). Breath-hold time was consistent within $0.3 \mathrm{~s}$ for all five trials, and the average inspired volume was always $>90 \%$ of the FVC. The average alveolar volume was also maintained within $0.2 \mathrm{~L}$ for all trials.

The data show that $D \mathrm{~L}, \mathrm{NO}$ and, thus, $D \mathrm{~m}, \mathrm{CO}$ remained unaltered from trial one to trial five (table 3). However, compared with the first trial, $D \mathrm{~L}, \mathrm{CO}$ and $V_{\mathrm{c}}$ significantly decreased by the fourth $(-4 \pm 5 \%$; $95 \%$ confidence interval (CI) $-5--2 \% ; \mathrm{p}<0.05)$ and third trial $(-5 \pm 7 \% ; 95 \%$ CI $-7--2 \%$; $\mathrm{p}<0.05)$, respectively. When $\mathrm{Dm}, \mathrm{CO}=D \mathrm{~L}, \mathrm{NO} / 2.42$, the per cent predicted based on age, height and sex was $111 \pm 31 \%$ (range $62-164 \%$; $<<0.05$ ), but when $D \mathrm{~m}, \mathrm{CO}=\mathrm{DL}, \mathrm{NO} / 1.97$, the per cent predicted was $136 \pm 39 \%(72-202 \% ; \mathrm{p}<0.05)$. For $V_{\mathrm{c}}$, when $\mathrm{Dm}, \mathrm{CO}=\mathrm{DL}, \mathrm{NO} / 2.42$ the per cent predicted based on height and sex was $116 \pm 19 \%(76-155 \% ; \mathrm{p}<0.05)$, but when $\mathrm{Dm}, \mathrm{CO}=$ $D \mathrm{~L}, \mathrm{NO} / 1.97$ the per cent predicted for $V_{\mathrm{C}}$ was $100 \pm 16 \%$ (66-131\%; $\mathrm{p}>0.05)$. Therefore, when $D \mathrm{~m}, \mathrm{CO}=D \mathrm{~L}, \mathrm{NO} / 2.42$, the $D \mathrm{~m}, \mathrm{CO}$ is reduced closer to normative values and the $V_{\mathrm{c}}$ is increased above normative values. The opposite occurs when $\mathrm{Dm}, \mathrm{CO}=D \mathrm{~L}, \mathrm{NO} / 1.97$ as the $D \mathrm{~m}, \mathrm{CO}$ is largely increased above the predicted value, but $V_{\mathrm{c}}$ is reduced to $100 \%$ pred.

The measurement error and repeatability of five trials are presented in table 4 . The repeatability represents the critical value in which a clinically measurable change in a given patient occurs between sessions. From the repeated measures ANOVA, a real clinical change in a patient's pulmonary diffusion capacity and its components was 17.2 and $3.2 \mathrm{~mL} \cdot \mathrm{min}^{-1} \cdot \mathrm{mmHg}^{-1}$ for $\mathrm{DL}, \mathrm{NO}$ and $\mathrm{DL}, \mathrm{CO}$, respectively.

TABLE 1 Subject characteristics and resting spirometry

\begin{tabular}{|c|c|c|c|}
\hline & Mean \pm SD (range) & Predicted & $\%$ predicted \\
\hline Females $\mathbf{n}$ & 15 & & \\
\hline Age yrs & $33 \pm 9(18-56)$ & & \\
\hline Weight kg & $68.6 \pm 12.5(49.4-98.8)$ & & \\
\hline Height $\mathrm{cm}$ & $169.9 \pm 9.0(155-189.5)$ & & \\
\hline FEV 1 L & $3.93 \pm 0.67(2.77-5.67)$ & $3.73 \pm 0.61(2.73-5.00)$ & $106 \pm 11(89-126)$ \\
\hline FVC L & $4.89 \pm 0.84(3.28-6.57)$ & $4.54 \pm 0.81(3.43-6.23)$ & $109 \pm 12(87-134)$ \\
\hline $\mathrm{FEV}_{1 / \text { FVC }}$ & $0.81 \pm 0.06(0.67-0.92)$ & & \\
\hline PEF L. $\mathbf{S}^{-1}$ & $9.06 \pm 2.14(5.71-13.90)$ & $8.52 \pm 1.54(6.49-11.33)$ & $106 \pm 13(84-140)$ \\
\hline FEF25-75 L.s ${ }^{-1}$ & $4.86 \pm 1.19(2.81-8.03)$ & $3.81 \pm 0.53(2.74-4.77)$ & $127 \pm 23(87-177)^{*}$ \\
\hline
\end{tabular}


TABLE 2 Characteristics of the five sequential single breath-hold manoeuvres in 31 subjects

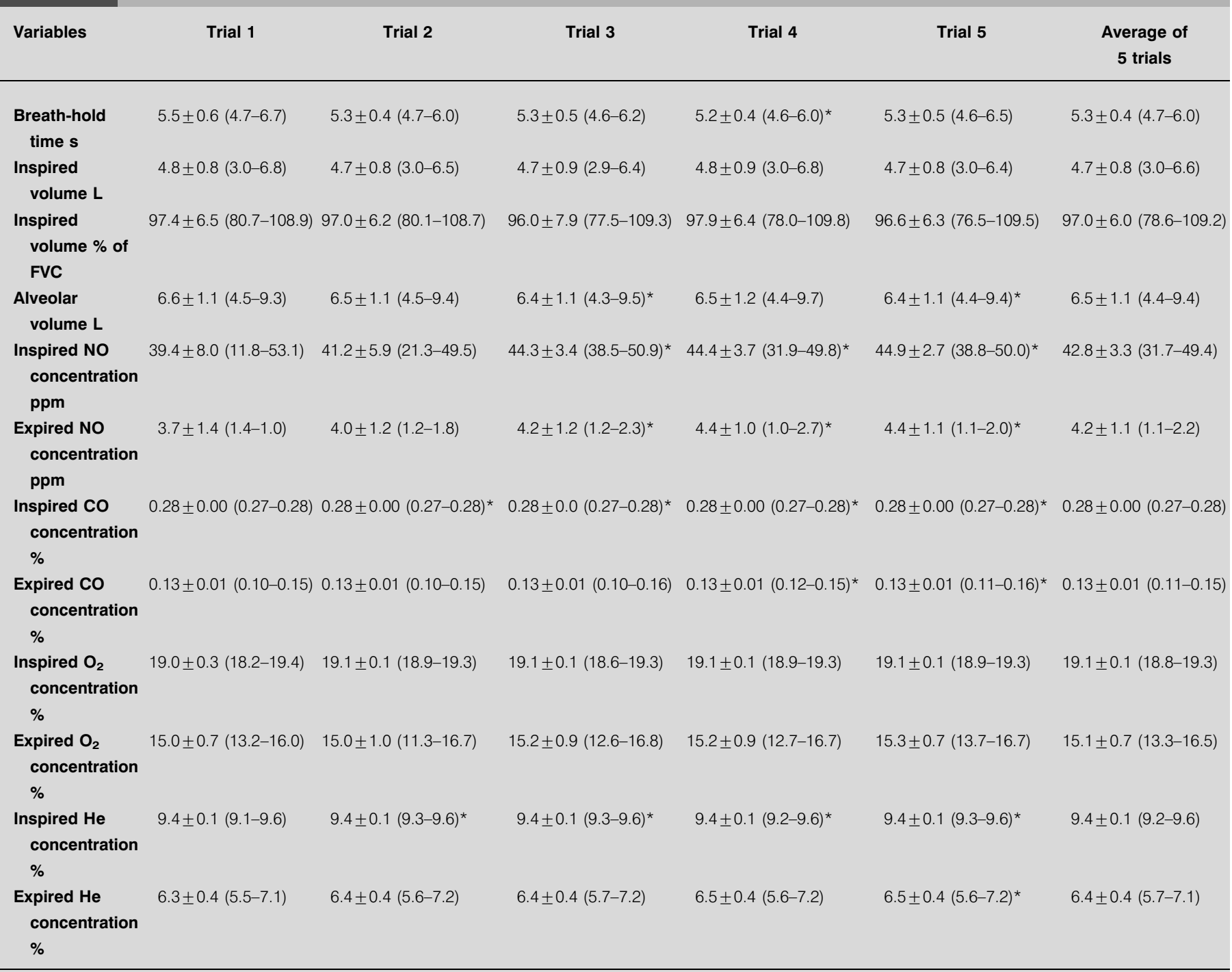

Data are presented as mean \pm SD (range). FVC: forced vital capacity; NO: nitric oxide; CO: carbon monoxide; $\mathrm{O}_{2}$ : oxygen; He: helium. *: significantly different from trial one $(p<0.05)$. The breath-hold time includes inspiration time plus apnoea time.

When $D \mathrm{~m}, \mathrm{CO}=D \mathrm{~L}, \mathrm{NO} / 2.42$, a real clinical change for $D \mathrm{~m}, \mathrm{CO}$ and $V_{\mathrm{c}}$ were $7.1 \mathrm{~mm} \cdot \mathrm{min}^{-1} \cdot \mathrm{Hg}^{-1}$ and $13 \mathrm{~mL}$, respectively. When $D \mathrm{~m}, \mathrm{CO}=D \mathrm{~L}, \mathrm{NO} / 1.97$, a real clinical change for $D \mathrm{~m}, \mathrm{CO}$ and $V_{\mathrm{c}}$ was any change $>8.7 \mathrm{~mL} \cdot \mathrm{min}^{-1} \cdot \mathrm{mmHg}^{-1}$ and $9.8 \mathrm{~mL}$, respectively.

The variables age, weight and height were examined by forward stepwise multiple regression to predict $D \mathrm{~L}, \mathrm{NO}$ values at rest. The only variable that appreciably affected $D \mathrm{~L}, \mathrm{NO}$ was height. Predicted $\mathrm{DL}, \mathrm{NO}$ in $\mathrm{mL} \cdot \mathrm{min}^{-1} \cdot \mathrm{mmHg}^{-1}=2.0164 \times$ height in $\mathrm{cm}-175.63 \quad\left(\mathrm{r}^{2}=0.39 ; \mathrm{SEE}=23.3\right)$. Adding the other two variables to the equation did not increase the coefficient of determination significantly. Therefore, DL,NO at rest was best predicted by height.

\section{DISCUSSION}

The present study showed that repeated inhalations of 40 50 ppm NO during single breath-hold manoeuvres does not increase $D \mathrm{~L}, \mathrm{NO}, D \mathrm{~m}, \mathrm{CO}, D \mathrm{~L}, \mathrm{CO}$ or $V_{\mathrm{c}}$. In fact, five sequential breath-hold manoeuvres did not change DL,NO and, thus, $D$ m,CO. However, DL,CO significantly decreased by the fourth trial, and $V_{\mathrm{c}}$ significantly decreased by the third trial. The drop in $D \mathrm{~L}, \mathrm{CO}$ by the fourth trial due to progressive increase in carboxyhaemoglobin was similar to that reported elsewhere [33]. As such, the data show that the actual number of tests required to provide a reasonable estimate of $D \mathrm{~L}, \mathrm{NO}, \mathrm{DL}, \mathrm{CO}$, $D$ m,CO and $V_{\text {c }}$ during properly performed manoeuvres is two trials. The average of the two trials should then be reported. Any more than two properly performed manoeuvres will lower $V_{\mathrm{c}}$, and more than three will lower $D \mathrm{~L}, \mathrm{CO}$. Therefore, two properly performed manoeuvres are sufficient to obtain all the components of lung diffusion capacity using the $D \mathrm{~L}, \mathrm{NO}-\mathrm{DL}, \mathrm{CO}$ method.

There has been some concern that NO may affect the pulmonary microcirculation due to its vasoactive properties 


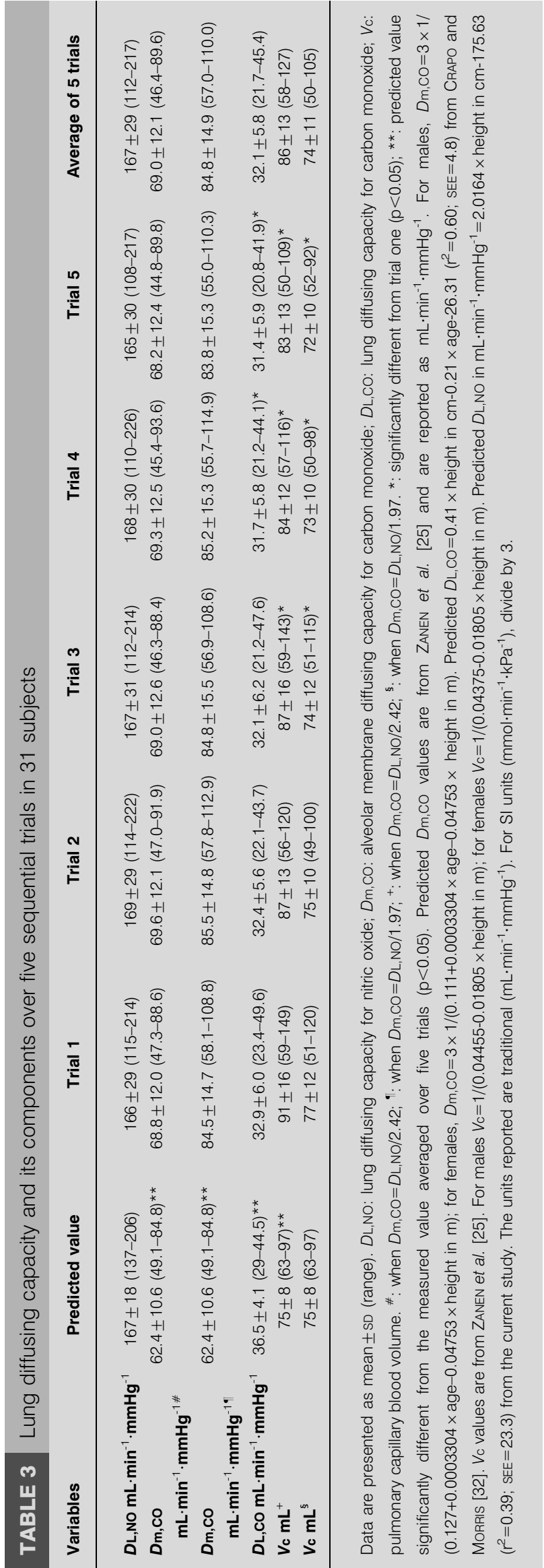

\begin{tabular}{|c|c|c|c|}
\hline \multirow{2}{*}{$\begin{array}{l}\text { TABLE } 4 \\
\text { Variable }\end{array}$} & \multicolumn{3}{|c|}{$\begin{array}{l}\text { Measurement error and repeatability of lung } \\
\text { diffusing capacity and its components for } 31 \\
\text { subjects }\end{array}$} \\
\hline & & Measurement error ${ }^{\#}$ & Repeatability \\
\hline \multicolumn{2}{|c|}{$D \mathrm{~L}, \mathrm{NO} \mathbf{m L} \cdot \mathrm{min}^{-1} \cdot \mathrm{mmHg}^{-1}$} & 6.2 & 17.2 \\
\hline \multicolumn{2}{|c|}{ Dm,co $\mathrm{mL} \cdot \mathrm{min}^{-1} \cdot \mathrm{mmHg}^{-1+}$} & 2.6 & 7.1 \\
\hline \multicolumn{2}{|c|}{$\mathrm{Dm}, \mathrm{CO} \mathrm{mL} \cdot \mathrm{min}^{-1} \cdot \mathrm{mmHg}^{-1 \S}$} & 3.2 & 8.7 \\
\hline \multicolumn{2}{|c|}{$D \mathrm{~L}, \mathrm{CO} \mathrm{mL} \cdot \mathrm{min}^{-1} \cdot \mathrm{mmHg}^{-1}$} & 1.2 & 3.2 \\
\hline \multicolumn{2}{|c|}{$V_{c} \mathbf{m L}^{+}$} & 4.7 & 13.0 \\
\hline \multicolumn{2}{|l|}{$V_{c} \mathrm{~mL}^{\S}$} & 3.5 & 9.7 \\
\hline \multicolumn{4}{|c|}{ 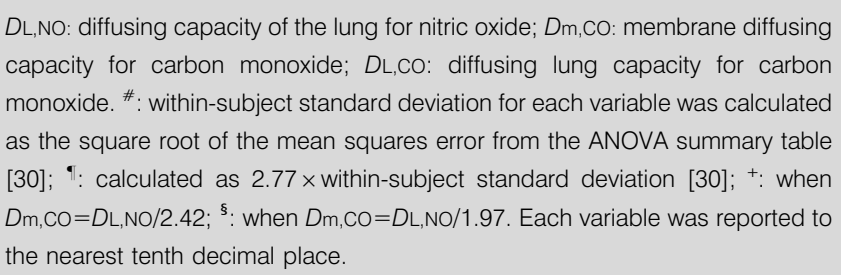 } \\
\hline
\end{tabular}

[22]. One study showed that there is a small nonsignificant increase in $D \mathrm{~L}, \mathrm{CO}$ in the presence of NO [17]. However, the current authors have shown that brief exposure to NO does not interfere with physiological function. Other human [11, 12, 20, 21] and animal studies [34] are in agreement with the present study. Rebreathing 20-40 ppm NO over $16 \mathrm{~s}$ to $10 \mathrm{~min}$ resulted in no significant changes to oxygen uptake, arterial oxygen tension, alveolar-arterial oxygen tension difference, $D \mathrm{~L}, \mathrm{CO}, \mathrm{Dm}$ or $V_{\mathrm{c}}$ in sick and healthy subjects at rest or during exercise $[11,12,21]$. In mechanically ventilated rabbits, $D \mathrm{~L}, \mathrm{NO}$ values remained unchanged despite inspiratory NO concentrations varying from 10-800 ppm [34]. Furthermore, the pulmonary toxicity of inhaled NO at concentrations of $\sim 40 \mathrm{ppm}$ over a prolonged period of time is minimal [35].

There is concern that different $P \mathrm{~A}_{1} \mathrm{O}_{2}$ may slightly alter $D \mathrm{~L}, \mathrm{NO}$ [36]. However, more recent data has shown that varying the $P_{A}, \mathrm{O}_{2}$ in those with or without pulmonary disease does not affect $D \mathrm{~L}, \mathrm{NO}[11,12]$, implying that the combined $D \mathrm{~L}, \mathrm{NO}-D \mathrm{~L}, \mathrm{CO}$ method can be used in hypoxaemic patients. Therefore, taken together, there is no reason to refrain from using $\mathrm{NO}$ and $\mathrm{CO}$ concurrently as a test gas to assess lung diffusion capacity.

The clinical implication of using both $\mathrm{NO}$ and $\mathrm{CO}$ concurrently in research and medical practice is that scientists and clinicians can immediately partition and quantify the components of lung diffusing capacity in a subject from a single 4-s breathhold manoeuvre that requires minimal effort on the part of the patient, while simultaneously being able to pinpoint which component $\left(V_{c}, D \mathrm{~m}\right)$ is causing low (or high) total lung diffusion capacities. The ability to estimate $D \mathrm{~m}, \mathrm{CO}$ and $V_{\mathrm{c}}$ from one-step simultaneous measurement of $D \mathrm{~L}, \mathrm{NO}$ and $D \mathrm{~L}, \mathrm{CO}$ represents significant conceptual advantages. One conceptual advantage of the $D \mathrm{~L}, \mathrm{NO}$ technique is that with the standard Roughton-Forster method, cardiac output can vary between measurements of $D \mathrm{~L}, \mathrm{CO}$ at different $\mathrm{O}_{2}$ tensions, which then have to be interpolated to obtain $\mathrm{DL}, \mathrm{CO}$ at two $\mathrm{O}_{2}$ tensions, but at the same cardiac output [12]. With the DL,NO method, all measurements are obtained at the same cardiac output and $\mathrm{O}_{2}$ tension; no interpolation is necessary. Another conceptual 
advantage is that with the traditional method, the distribution of $\mathrm{CO}$ gas in the lungs may be different at two different $\mathrm{O}_{2}$ tensions, but with the $D \mathrm{~L}, \mathrm{NO}$ method only one inspiration is required, which results in a similar distribution of $\mathrm{NO}$ and $\mathrm{CO}$ gases. A third conceptual advantage is that with the traditional method, there is systematic underestimation of $V_{c}$ and an overestimation of $D$ m since the inspiration at two different $\mathrm{O}_{2}$ tensions affects alveolar-capillary membrane diffusion [37]. The DL,NO-DL,CO method avoids this error altogether and should improve the accuracy of estimated $D \mathrm{~m}, \mathrm{CO}$ and $V_{\mathrm{c}}$.

The ratio $D \mathrm{~m}, \mathrm{CO}=D \mathrm{~L}, \mathrm{NO} / 2.42$ gives a better estimate of $D \mathrm{~m}$. When the present measured values were compared against the published norms, using the traditional two-step RoughtonForster method [25], the predicted $D \mathrm{~m}, \mathrm{CO}$ was $136 \%$ pred when $D \mathrm{~m}, \mathrm{CO}=D \mathrm{~L}, \mathrm{NO} / 1.97$, but only $111 \%$ pred when $\mathrm{Dm}, \mathrm{CO}=$ $D \mathrm{~L}, \mathrm{NO} / 2.42$. However, the better per cent predicted values for $V_{\mathrm{c}}$ occurred when $D \mathrm{~m}, \mathrm{CO}=D \mathrm{~L}, \mathrm{NO} / 1.97$. Nonetheless, since the traditional Roughton-Forster method underestimates $V_{\mathrm{c}}$, the current authors feel that the predicted $V_{\mathrm{C}}$ values by ZANEN et al. [25] slightly underestimate $V_{\mathrm{c}}$. Therefore, the best compromise is to estimate $D \mathrm{~m}$ and $V_{\mathrm{c}}$ from a single breath using the $D \mathrm{~L}, \mathrm{NO}-D \mathrm{~L}, \mathrm{CO}$ method and the formula $D \mathrm{~m}, \mathrm{CO}=D \mathrm{~L}, \mathrm{NO} / 2.42$.

It was also important to clarify the repeatability of lung diffusion capacity and its components over five trials from the single-breath $D$ L,NO-DL,CO method. The repeatability allows clinicians to identify a true clinically meaningful change from measurement error. The difference between any two measurements for the same subject is expected to be $<2.77$ multiplied by the within-subject standard deviation; therefore, the repeatability was defined as 2.77 multiplied by the withinsubject standard deviation obtained from the ANOVA [30]. Table 4 shows a true measurable clinical change in $D \mathrm{~L}, \mathrm{NO}$ and $\mathrm{DL}, \mathrm{CO}$ as an absolute change of $>17$ and $3 \mathrm{~mL} \cdot \mathrm{min}^{-1} \cdot \mathrm{mmHg}^{-1}$, respectively. In addition, a true clinical change in $\mathrm{Dm}, \mathrm{CO}$ and $V_{\mathrm{c}}$ is an absolute change of $>7 \mathrm{~mL} \cdot \mathrm{min}^{-1} \cdot \mathrm{mmHg}^{-1}$ and $13 \mathrm{~mL}$, respectively. Any change that is less than these values is considered a true measurement error. Indeed, $D \mathrm{~m}, \mathrm{CO}$ equals $D$ L,NO divided by a fixed value, and $V_{\mathrm{c}}$ is derived from the $D \mathrm{~L}, \mathrm{NO}$ and $D \mathrm{~L}, \mathrm{CO}$; therefore the repeatability of $D \mathrm{~m}$ and $V_{\mathrm{c}}$ can be calculated from (or explained by) the repeatability of the DL,NO.

Based on ATS and ERS criteria, the average value of two trials whose difference in diffusing capacity is within $10 \%$ of each other is considered acceptable. The present authors looked at the average $D \mathrm{~L}, \mathrm{NO}$ and $D \mathrm{~L}, \mathrm{CO}$ for all 31 subjects over five trials, and the repeatability data of this study are in agreement with the ATS/ERS guidelines as DL,NO (and thus Dm,CO) and DL,CO are found to be $10 \%$. However, since the variability of the parameters $D \mathrm{~L}, \mathrm{NO}$ and $\mathrm{DL}, \mathrm{CO}$ were independent of the magnitude of the measurement, the results invalidate the use of percentage value to describe the repeatability. Using a percentage will lead to underestimation of variability in low values and overestimation for high values. Others studies have also suggested using an absolute value rather than a percentage, since the diffusing capacity was also independent of the magnitude of the measurement $[38,39]$. Therefore, the current authors recommend using an absolute difference rather than a percentage as alternative criteria for repeatability. It is also recommended to report the average of two trials when the absolute difference between the two measurements is within $17 \mathrm{~mm} \cdot \mathrm{min}^{-1} \cdot \mathrm{mmHg}^{-1}$ for $\mathrm{DL}, \mathrm{NO}, 3 \mathrm{~mm} \cdot \mathrm{min}^{-1} \cdot \mathrm{mmHg}^{-1}$ for $D \mathrm{~L}, \mathrm{CO}$, and $13 \mathrm{~mL}$ for $V_{\mathrm{c}}$.

It is believed that the present paper is the first to actually quantify important measurable clinical changes in the parameters obtained from the single-breath $\mathrm{DL}, \mathrm{NO}-\mathrm{DL}, \mathrm{CO}$ method.

\section{Conclusion}

Small amounts of nitric oxide inhaled during sequential singlebreath manoeuvres have no effect on lung diffusing capacity for nitric oxide and, thus, membrane diffusing capacity for carbon monoxide. The recommended ratio is membrane diffusing capacity for carbon monoxide=lung diffusing capacity for nitric oxide/2.42. As more than two and three singlebreath manoeuvres will lower pulmonary capillary blood volume and lung diffusing capacity for carbon monoxide, respectively, the average value of the first two trials are recommended to provide a reasonable estimate of lung diffusing capacity for nitric oxide, lung diffusing capacity for carbon monoxide, membrane diffusing capacity for carbon monoxide and pulmonary capillary blood volume.

\section{REFERENCES}

1 Roughton FJW, Forster RE. Relative importance of diffusion and chemical reaction rates in determining rate of exchange of gases in the human lung, with special reference to true diffusing capacity of pulmonary membrane and volume of blood in the lung capillaries. J Appl Physiol 1957; 11: 290-302.

2 Hsia CC. Recruitment of lung diffusing capacity: update of concept and application. Chest 2002; 122: 1774-1783.

3 Hughes JM. The single breath transfer factor $(\mathrm{Tl}, \mathrm{Co})$ and the transfer coefficient (Kco): a window onto the pulmonary microcirculation. Clin Physiol Funct Imaging 2003; 23: 63-71.

4 Borland CD, Higenbottam TW. A simultaneous single breath measurement of pulmonary diffusing capacity with nitric oxide and carbon monoxide. Eur Respir J 1989; 2: 56-63.

5 Guenard H, Varene N, Vaida P. Determination of lung capillary blood volume and membrane diffusing capacity in man by the measurements of $\mathrm{NO}$ and $\mathrm{CO}$ transfer. Respir Physiol 1987; 70: 113-120.

6 Meyer M, Piiper J. Nitric oxide (NO), a new test gas for study of alveolar-capillary diffusion. Eur Respir J 1989; 2: 494-496.

7 Johnson RL Jr, Heigenhauser GJF, Hsia CCW, Jones NL, Wagner PD. Determinants of gas exchange and acidbalance during exercise. In: Rowell LB, Shepard JT, eds. Handbook of Physiology. Section 12: Exercise: Regulation and Integration of Multiple Systems. New York, Oxford University Press, 1996; pp. 515-584.

8 van der Lee I, Zanen P, Biesma DH, van den Bosch JM. The effect of red cell transfusion on nitric oxide diffusing capacity. Respiration 2005; 72: 512-516.

9 Manier G, Moinard J, Stoicheff H. Pulmonary diffusing capacity after maximal exercise. J Appl Physiol 1993; 75: 2580-2585. 
10 Manier G, Moinard J, Techoueyres P, Varene N, Guenard H. Pulmonary diffusion limitation after prolonged strenuous exercise. Respir Physiol 1991; 83: 143-153.

11 Tamhane RM, Johnson RL Jr, Hsia CC. Pulmonary membrane diffusing capacity and capillary blood volume measured during exercise from nitric oxide uptake. Chest 2001; 120: 1850-1856.

12 Phansalkar AR, Hanson CM, Shakir AR, Johnson RL Jr, Hsia CC. Nitric oxide diffusing capacity and alveolar microvascular recruitment in sarcoidosis. Am J Respir Crit Care Med 2004; 169: 1034-1040.

13 Zavorsky GS, Quiron KB, Massarelli PS, Lands LC. The relationship between single-breath diffusion capacity of the lung for nitric oxide and carbon monoxide during various exercise intensities. Chest 2004; 125: 1019-1027.

14 Zavorsky GS, Lands LC. Lung diffusion capacity for nitric oxide and carbon monoxide is impaired similarly following short-term graded exercise. Nitric Oxide 2005; 12: 31-38.

15 Roughton $\mathrm{FJH}$, Gibson $\mathrm{QH}$. The kinetics and equilibrium reactions of nitric oxide with sheep hemoglobin. J Physiol 1957; 136: 507-526.

16 Moinard J, Guenard H. Determination of lung capillary blood volume and membrane diffusing capacity in patients with COLD using the NO-CO method. Eur Respir J 1990; 3: 318-322.

17 Tsoukias NM, Dabdub D, Wilson AF, George SC. Effect of alveolar volume and sequential filling on the diffusing capacity of the lungs: II. Experiment. Respir Physiol 2000; 120: 251-271.

18 Perillo IB, Hyde RW, Olszowka AJ, et al. Chemiluminescent measurements of nitric oxide pulmonary diffusing capacity and alveolar production in humans. J Appl Physiol 2001; 91: 1931-1940.

19 Vaida P, Kays C, Riviere D, Techoueyres P, Lachaud JL. Pulmonary diffusing capacity and pulmonary capillary blood volume during parabolic flights. J Appl Physiol 1997; 82: 1091-1097.

20 Brett SJ, Chambers J, Bush A, Rosenthal M, Evans TW. Pulmonary response of normal human subjects to inhaled vasodilator substances. Clin Sci (Lond) 1998; 95: 621-627.

21 Sheel AW, Edwards MR, Hunte GS, McKenzie DC. Influence of inhaled nitric oxide on gas exchange during normoxic and hypoxic exercise in highly trained cyclists. J Appl Physiol 2001; 90: 926-932.

22 van der Lee I, Zanen P. Diffusion capacity for nitric oxide and carbon monoxide. Chest 2004; 126: 1708-1709, author reply $1709-1710$.

23 Macintyre N, Crapo RO, Viegi G, et al. Standardisation of the single-breath determination of carbon monoxide uptake in the lung. Eur Respir J 2005; 26: 720-735.

24 Jones RS, Meade F. A theoretical and experimental analysis of anomalies in the estimation of pulmonary diffusing capacity by the single breath method. Q J Exp Physiol 1961; 46: 131-143.

25 Zanen P, van der Lee L, van der Mark T, van den Bosch JM. Reference values for alveolar membrane diffusion capacity and pulmonary capillary blood volume. Eur Respir J 2001; 18: 764-769.

26 Turcotte RA, Perrault H, Marcotte JE, Beland M. A test for the measurement of pulmonary diffusion capacity during high-intensity exercise. J Sports Sci 1992; 10: 229-235.

27 Iwamoto J, Pendergast DR, Suzuki H, Krasney JA. Effect of graded exercise on nitric oxide in expired air in humans. Respir Physiol 1994; 97: 333-345.

28 Pogliaghi S, Krasney JA, Pendergast DR. Effect of gravity on lung exhaled nitric oxide at rest and during exercise. Respir Physiol 1997; 107: 157-164.

29 Ogilvie CM, Forster RE, Blakemore WS, Morton JW. A standardized breathholding technique for the clinical measurement of diffusing capacity for the lung for carbon monoxide. J Clin Invest 1957; 36: 1-17.

30 Bland JM, Altman DG. Measurement error. BMJ 1996; 313: 744.

31 Hankinson JL, Odencrantz JR, Fedan KB. Spirometric reference values from a sample of the general U.S. population. Am J Respir Crit Care Med 1999; 159: 179-187.

32 Crapo RO, Morris AH. Standardized single breath normal values for carbon monoxide diffusing capacity. Am Rev Respir Dis 1981; 123: 185-189.

33 Frey TM, Crapo RO, Jensen RL, Elliott CG. Diurnal variation of the diffusing capacity of the lung: is it real? Am Rev Respir Dis 1987; 136: 1381-1384.

34 Heller H, Schuster KD. Single-breath diffusing capacity of $\mathrm{NO}$ independent of inspiratory $\mathrm{NO}$ concentration in rabbits. Am J Physiol 1997; 273: R2055-R2058.

35 Hugod C. Effect of exposure to 43 ppm nitric oxide and $3.6 \mathrm{ppm}$ nitrogen dioxide on rabbit lung. A light and electron microscopic study. Int Arch Occup Environ Health 1979; 42: 159-167.

36 Borland CD, Cox Y. Effect of varying alveolar oxygen partial pressure on diffusing capacity for nitric oxide and carbon monoxide, membrane diffusing capacity and lung capillary blood volume. Clin Sci (Colch) 1991; 81: 759-765.

37 Hsia CC, Chuong CJ, Johnson RL Jr. Critique of conceptual basis of diffusing capacity estimates: a finite element analysis. J Appl Physiol 1995; 79: 1039-1047.

38 Robson AG, Innes JA. Short term variability of single breath carbon monoxide transfer factor. Thorax 2001; 56: 358-361.

39 Punjabi NM, Shade D, Patel AM, Wise RA. Measurement variability in single-breath diffusing capacity of the lung. Chest 2003; 123: 1082-1089. 